\title{
Politics As Medicine: On Misdiagnosing Legal Scholarship
}

\author{
Frank I. Michelman ${ }^{\dagger}$
}

Here it is, Sunday morning. Something in the structure of the situation makes me think it must be my role to counter Mark Tushnet's message of despair with the message of hope-and to wrestle with Alan Freeman for the soul of Paul Brest.

The problem posed to us by Professor Tushnet is the failure of contemporary legal scholarship, as he sees it, to participate significantly in what he takes to be the one true intellectual calling of our times: coming to terms with the demon of subjectivity in human inquiry, both descriptive and normative.

One, and I think the less interesting, of Professor Tushnet's explanatory theses is that legal scholars are, by and large, the same people as law professors. That is, we are people whose job it is to teach advocates, and in whose teaching role subjectivity-the insuperable partiality of learned discourse-is not a problem, but a premise. That observation may help explain the marginality of some legal scholarship. I doubt, though, that it reflects, as Professor Tushnet suggests it does, the demand for "professionalism" in legal education. Every teacher here knows there is no logical inconsistency, nor even (for the teacher) any serious dissonance, involved in trying to show students how legal arguments are made, and how they are made persuasive, while trying at the same time to show students (if that is one's line) that legal arguments necessarily lack logical compulsion or any other kind of objective validity. The last lesson, if true, is obviously one that every professionally competent lawyer ought to understand. Thus, law teaching that overlooks the problem of judicial and other legal subjectivity is not necessitated by the "dilemmas of professional education in an academic setting"; ${ }^{1}$ it is simply inadequate teaching. It is not, then, "in their role as teachers of lawyers" that legal scholars are blocked (insofar as they are blocked) from in-

+ Professor of Law, Harvard University.

1. Tushnet, Legal Scholarship: Its Causes and Cure, 90 YALE L.J. 1205, 1206 (1981).

2. Id. 
volvement in contemporary intellectual life as Professor Tushnet conceives it.

I do not, of course, mean to deny what Professor Kronman said in his introductory remarks: that advocacy may be habit-forming and may atrophy the faculty of more detached appraisal. ${ }^{3}$ Nor do I mean to deny the existence of pressures that may deflect law teachers from teaching and scholarship that seriously confront the issue of subjectivity in legal ordering. The notion of the rule of law is, as Professor Tushnet says, a crucial component of our society's prevailing ideas about the legitimacy of democratic political institutions. The rule of law is also a part of the liberal solution to the dilemmas of individuality and society, of freedom and order-to what Professor Tushnet, speaking at the level of theory, calls "the conflict between objectivity and subjectivity." $\mathrm{He}$ is, furthermore, correct to state that "the conflict between objectivity and subjectivity cannot readily be confronted within the legal sphere" in ways that do not undermine the rule of law. ${ }^{5}$ It is a plausible hypothesis that there are, as a result, ideological pressures on law teachers to steer clear of thought or utterance that threatens the sense of legitimacy by confounding the rule of law. Certainly that hypothesis is one upon which each of us can reflect and to which each of us can try to respond out of our own experience. What we as educators should be clear about is that such pressures as there may be arise not out of any canon of "professionalism" in legal education, but out of law's crucial position in liberal political thought. Professor Tushnet's first explanation of the alleged depravity of legal scholarship is strictly parasitic on his second.

The second explanation, in a nutshell, is that legal scholarship suffers from its flight from Realism, its refusal to accept the Wittgensteinian critique of rules, its inability to rise above the liberal fancy that "human behavior can be governed by rules that have some supraindividual content" that enables them somehow to "reconcile subjectivity and objectivity."' The bane of legal scholarship, according to this diagnosis, is the notion of the rule of law.

Speaking very roughly, we can say that the liberal rule-of-law solution to the dilemma of subjectivity and objectivity in political life requires both a lawmaking process that conforms to liberal norms

3. See Kronman, Foreword: Legal Scholarship and Moral Education, 90 YALE L.J. 955, 964-65 (1981).

4. Tushnet, supra note 1 , at 1206 .

5. Id. at 1207 (emphasis added).

6. Id. at 1207, 1222 . 
of individuality-of equality and consent-and a resulting corpus $j u r i s$ capable of impartially resolving all disputes that may arise. That is not, to be sure, a simple prescription to fill. Of the many complications that might be noted, one cluster deserves special mention here: there is little chance than any corpus juris will be sufficiently complete and detailed to resolve particular disputes without some exercise of lawmaking authority by the adjudicative tribunal itself; but it is unclear either how such exercises of authority could be objectively certified as impartial or how a constitutional system that allows for them could be found to conform to norms of equality and consent. The answers to these problems are not, to use Professor Tushnet's adverb, "readily" available. I cannot see, however, how it follows that searching for answers is a misguided, an arid, or an intellectually marginal enterprise.

We might dwell for just a moment on the problem of the liberal constitution. How should one specify the basic norms of individuality and equality? By what mode of discourse-utilitarian, contractarian, "neutral dialogue," or something else? What constitution will satisfy the basic norms? Scholarship addressed to those questions of liberal political theory is hardly beside the point of the subjective-objective dilemma. Is it, even so, doomed to intellectual marginality? Is Rawls an intellectually marginal figure? Is Nozick? (It is too soon to ask, is Ackerman?)

It may be true that these days it is not primarily lawyers, but nonlawyer philosophers, economists, and political scientists, who are doing basic liberal constitutional theory; and surely it is true that 'twas not ever thus. Perhaps, then, there is something that tends to confine contemporary legal scholarship to the edge of town. If so, however, it seems to me on the evidence so far adduced that, whatever the something is, liberal ideology ain't it.

It might be said that lawyers qua lawyers do their distinctive thing at the level of applying the law to cases. Is it not clear, the argument would go, that, at that level, the liberal mystification of the Rule of Law blocks scholars from life-giving engagement with the issue of subjectivity? I see little reason to think so.

Professor Tushnet mentions Wittgenstein's Philosophical Investigations" as the "fancy citation" for the idea that rules and rule systems are ineradicably indeterminate. ${ }^{8}$ It is worth remembering just

7. L. Wittgenstein, Philosophical Investigations (3d ed. G. Anscombe trans. 1973).

8. Tushnet, supra note 1 , at 1217 n.51. 
what lessons Wittgenstein taught. From Wittgenstein we learned that a set of instructions can never finish explaining how itself is to be read; the signpost on the road fails to tell us whether to go in the direction of the point or the butt. The Wittgensteinian lesson, however, does not end there. It goes on to insist that judgments of error, mistake, and incompetency in the use of rules are nonetheless possible within a practice, a language-game, or a form of life. One can say, for example, that a traveler striking off in the direction of the butt-end of a road sign has failed to read the sign correctly.

The latter part of the lesson has implications for liberal legal theory no less significant than those of the first part. At the very least, it seems to mean that in no case is the set of admissible judicial responses-decisions and reasons-unbounded. It may mean, further, that there are at least some "easy cases" in which the set of admissible responses contains only one member.

No doubt those observations alone are not enough to salvage liberal legalism from Realist attack, but neither are they irrelevant. They leave open a number of avenues for scholarship to follow: What degree of "openness," if any, can a liberal legal order tolerate without losing its legitimacy on liberal premises such as those of equality and consent? What modes of criticism of judicial judgment are available? How sharply can criticism reduce the population of hard cases and narrow the set of admissible decisions and reasons? What are the alternatives? Granting that a liberal legal order does entail for each of us a partial surrender to judicial authority figures of our own innate authority to determine the law for ourselves, are there alternatives that are better or more just? And, again, what is the meta-theory for dealing with that question?

All of those questions, and more, invite inquiry within a liberal "paradigm"; all are addressed to the subjective-objective dilemma; all may yet lead in directions and to legal and political ideas yet undreamed. Who is to say not?

There may be something deeply, morally wrong with the fundamental liberal commitment to the separate life of the individual. I cannot quite bring myself to think so (there you have my confession for this Sunday morning), but there may be. For scholars who think otherwise-for whom that liberal commitment to separate individuality is a considered and chosen commitment-what choice is there but to wrestle with the demon of subjectivity on liberal turf and on liberal terms? The point $I$ insist on is that one can do that: liberalism as such is not an intellectual contrivance for repressing 
the problem of subjectivity from consciousness; it is a way of framing and posing the problem.

Let me end by recalling Paul Brest's paper, which in many ways overlaps with Mark Tushnet's. The quest recounted in Paul's paper sounded to me like a liberal quest, the pilgrim like a liberal pilgrim, the grail like a liberal's grail. Who but a liberal would care that there may not be a "substantive value-neutral non-originalist mode of constitutional adjudication"?

Paul's discourse was precisely about the problem of subjectivity in law. For aught any listener could tell it was conducted entirely on liberal premises. The vision evoked towards its end, of a participatory public dialogue leading to the development of shared values out of individuals' thoughts and utterances, is, to my understanding, not antithetical to a reasonably ample liberalism but continuous with an important branch of the liberal tradition-the one spoken for by Arendt in On Revolution ${ }^{10}$ and, I believe, by Kant in the Groundwork: ${ }^{11}$ it is the Kantian vision of the Kingdom of Ends.

I think the issue comes down to this: intellectual cowardice-including not least the refusal to face honestly the problem of subjectivity in law-is a vice; but the name of the vice is "cowardice," not "liberalism." We have to hope it is given to some, sometimes, to rise above scholarly original sin. Granted that necessary if perhaps forlorn premise, I do not see that anything has been said to show that liberal hopes are especially incompatible with scholarly grace.

9. Brest, The Fundamental Rights Controversy: The Essential Contradictions of Normative Constitutional Scholarship, 90 YALE L.J. 1063 (1981).

10. H. ARENDT, ON Revolution (1965).

11. I. Kant, Groundwork of the Metaphysics of Morals (H. Paton trans. 1947). 